\title{
Identifying Demographic Variables Influencing the Nature of Science (NOS) Conceptions of Teachers
}

\author{
Ayhan Karaman \\ Faculty of Education, Sinop University, Turkey
}

Copyright $(2017$ by authors, all rights reserved. Authors agree that this article remains permanently open access under the terms of the Creative Commons Attribution License 4.0 International License

\begin{abstract}
In this survey research study, the views of practicing teachers in select aspects of NOS were investigated in connection with the effects of several variables (teaching discipline, gender, education level, teaching experience and regional work location). The instrument used to collect data was an adapted version of "Scientific Epistemological Views" questionnaire originally developed by Liu and Tsai [45]. The data collected from a total of 647 in-service teachers was analyzed conducting MANOVA statistical test. The results revealed that the variable, 'teaching discipline', had a statistically significant multivariate effect on the overall NOS conceptions of the participant teachers. Teachers' mean scores exhibited a statistically significant difference in three out of five sub-dimensions of the questionnaire. The variables, "gender" and "education level", yielded a statistically insignificant result, which indicated the ineffectual nature of those variables on participant teachers' views of NOS concepts. The variables, "teaching experience" and "regional work location", were found to be statistically significant in only one of the sub-dimensions of the questionnaire. At the end of the paper, these results were discussed in connection with the relevant education literature.
\end{abstract}

Keywords Nature of Science Conceptions, In-service Teachers, Science Education, Scientific Epistemological Views, Survey Research

\section{Introduction}

Recent technological innovations have made profound impacts on our lives. In parallel to the rapid development of communication technologies, reaching information resources have never been much easier in the past than today. However, together with a tremendous amount of trustworthy knowledge, the internet at the same time is home to a myriad of unreliable information produced and dispersed in each and every second. The importance of educating students with a sound understanding of the certain characteristics of the science is therefore more important today than ever before due to the increasing exposure of people to the unsupported claims made continuously in various media and internet sources. Preserving the vulnerable children from the ill effects of scientific myths, paranormal ideas, supernatural beliefs and pseudoscientific claims disseminated in a variety of media sources is crucially dependent on equipping them with the qualifications of scientific literacy. As opposed to all types of speculations circulating around, the science as one of the ways of knowing symbolizes the rational thinking and the empirical reasoning, which constitutes one of the most important qualifications for students to acquire in their science classes. That is the primary reason that scientific literacy has recently become the overarching objective of contemporary science education reform movements [29, 37, 62]. Developing an adequate understanding of the nature of science (NOS) concepts is one of the most essential ingredients of becoming a scientifically literate individual [2, $5,18,44,61,65]$.

There is a high consensus in the education community about the importance of introducing students to an accurate portrayal of science, which is consistent with the contemporary interpretations of science $[59,60,61]$. On the other hand, what characteristics of science reflect its authentic character is a controversial topic among scholars from different fields (e.g. philosophy, psychology, history, and sociology of science) $[32,49]$. Questions including, but not limited to, the following ones have long been the subject of debates made in the philosophy of science: What is science? What is the epistemological status of scientific knowledge? What are the distinguishing characteristics of science from other academic disciplines? How knowledge is generated and validated in science? What methods are used to produce scientific knowledge? How is science influenced by society and vice versa? Similar kind of questions posed by scholars indicates that there exists an ongoing dispute about the genuine nature of science in academic world [46]. The search for a criterion to differentiate science from non-science and pseudoscience, which is called "the 
demarcation problem", is still an unresolved issue in the philosophy of science. One's conception of science alters depending on the philosophical ground on which $\mathrm{s} / \mathrm{he}$ stands. The conceptions of science held by people range on a scale from traditional to postmodern interpretations of science $[4$, 24]. The heated discussions between the scholars who favor traditional and postmodern interpretations of science are pronounced by some as "science wars" [24, 54]. Science is conceptualized in general by traditionalists as an objective source of knowledge generated solely from the empirical data by using the prominent method of science. Postmodernists delineate science as one of the ways of knowing, which is influenced by the social and cultural values of the society, and emphasize the multiple methods used by scientists. In a nutshell, the unsettled academic discussions about science indicate that there is no single NOS to be endorsed by all scholars $[1,17]$. Some even go to say that there simply is no such thing as NOS [19]. Furthermore, as it is the case with the scientific knowledge, NOS is a dynamic rather than a static construct, which is always subject to change in time [41].

There is no doubt that NOS is one of the most essential constructs of science education to be engaged in by students in their science lessons. However, lack of a single understanding of NOS in the academic community creates a dilemma about what version of NOS is more appropriate for students to learn in their classrooms [6]. Contemporary science education programs at K-12 level include a list of NOS concepts acknowledged by many educators as suitable for the cognitive development of students and essential for overcoming several erroneous notions of students about science. Although the list of NOS concepts is by no means absolute, the following seven aspects of NOS have been emphasized extensively in science education literature [42]:

1. The empirical nature of scientific knowledge: Claims about natural phenomena to be acknowledged as scientific knowledge is eventually needed to be validated through observations. However, scientists do not have a direct access to the essence of most natural phenomena. This necessitates making inferences in order to establish the necessary link between the observations and the unexplained natural events.

2. The tentativeness of scientific knowledge: Due to the presence of a vast amount of empirical evidences behind scientific knowledge, it is durable yet not exempt from any changes in time. All scientific knowledge is potentially, at least in principal, open to change because none of the scientific knowledge has a claim to represent the absolute truth. As new evidences are discovered or existent evidences are reinterpreted as a consequence of the advances in technology, current scientific laws or theories are revised or replaced with the new ones.

3. The theory-laden nature of scientific knowledge: Scientists make their scientific investigations within the borders of certain paradigms. Therefore, theoretical perspectives shared by scientists in a specific paradigm influence their work. Assuming that scientists make completely neutral observations free from their prior experiences is not more than an oversimplified conception of the scientific research process. Theoretical considerations of scientists affect the whole scientific research process including, but not limited to, what specific problems to be investigated, which methods to be used in conducting the investigations, and how to interpret the available data.

4. The creative and imaginative nature of scientific knowledge: Scientific knowledge is generated through empirical observations of nature. However, science is not completely confined to direct observations of the natural phenomena. Scientists use their creativity and imagination in every stage of scientific investigations because science is more than "a lifeless, entirely rational, and orderly activity" [42]. In choosing the problems to investigate, building the appropriate set-ups to test their hypotheses, analyzing the available data, and making inferences about their results, scientists are boundless to involve their creativity and imagination.

5. The social and cultural embeddedness of scientific knowledge: Science is an unisolated activity from its environment but rather performed in a sociocultural context. Scientific knowledge "affects and is affected by the various elements and intellectual spheres of the culture in which it is embedded" [42]. Certain values of the society in which scientists grew up play a significant role in shaping their decision mechanisms while conducting their scientific investigations. Political structures, religious beliefs, philosophical assumptions, and economic status of the society all take a part in the practice of the scientific research.

6. The similarities and distinctions between scientific laws and theories: Scientific laws and theories are invaluable assets of science, which together serve human beings in their effort to understand the physical world around them. There is a common misconception among lay people that scientific theories turn into scientific laws once they are proved with sufficient evidences. Scientific laws and theories are two distinct sources of knowledge. "Laws are descriptive statements of relationships among observable phenomena....Theories, by contrast, are inferred explanations for observable phenomena or regularities in those phenomena" [42]. Hence, there exists no hierarchy between scientific laws and theories, which means that theories never become laws with sufficient amount of supportive evidences.

7. The nonexistence of the scientific method: There are multiple methods used by scientists in their scientific 
endeavors. Therefore, the existence of a universal stepwise scientific method used commonly by all scientists is no more than a myth. "It is true that scientists observe, compare, measure, test, speculate, hypothesize, create ideas and conceptual tools, and construct theories and explanations. However, there is no single sequence of activities (prescribed or otherwise) that will unerringly lead them to functional or valid solutions or answers, let alone certain or true knowledge" [42].

The aspects of NOS listed above is often called "Lederman seven" and promoted by science education community as "the consensus view" of NOS concepts [51]. Having such a list of NOS concepts is useful for introducing NOS to students, helping researchers devise instruments to measure students' learning of NOS, and encouraging teachers and students to think deeper about NOS matters [47]. On the other hand, the consensus list is surely not exempt from any criticism. "The list can, despite the wishes of its creators, function as a mantra, as a catechism, as yet another something to be learnt. Instead of teachers and students reading, analyzing, and coming to their own views about NOS matters, the list often short-circuits all of this" [47]. Mathews [47] proposed to call the consensus list as "features of science (FOS)" by considering it to be more appropriate to be engaged deeper by learners as opposed to the items in nature of science (NOS) which only offer a surface learning without giving much thought about them.

NOS concepts have recently become an indispensable instructional outcome of the renewed science education programs all over the world [43, 58]. However, integrating a topic into the education programs is one thing, yet teaching it successfully to the students is another one. The incompetency of teachers is one of the most noticeable barriers in front of giving an adequate education to students about NOS concepts. A considerable number of teachers working in elementary and secondary schools suffer from inadequate education that they received about NOS concepts $[3,4,26,55,65]$. This situation impedes the efforts spent on reforming science education. Therefore, helping practicing teachers improve their understanding of NOS concepts becomes an important priority for turning reform ideals into reality. Generating support strategies for teachers about NOS concepts is futile without first identifying the specific factors influencing their views of NOS concepts. An effort was made in this research study to determine the influential variables in teachers' comprehension of NOS concepts.

\subsection{Purpose and Significance of the Study}

Teachers play a key role in the successful implementation of the educational reforms. That is because reform ideas developed at the macro level of education are actualized primarily by teachers at the micro level of classrooms. In that sense, conducting research studies on practicing teachers is a good investment with a high return. Research studies dedicated to provide a comprehensive portrayal of practicing teachers' views of science would provide a considerable support to the efforts made to give a better education in NOS concepts to both pre-service and in-service teachers. In this research study, NOS conceptions of in-service teachers were investigated in connection with the effects of the following variables: teaching discipline of the teachers, gender of the teachers, education level of the teachers, teaching experience of the teachers and regional work locations of the teachers. Considering the limited number of research studies conducted with respect to NOS conceptions of Turkish in-service teachers, this research study would help to fill an important gap in the education literature. Any further action to be taken in teacher education is eventually dependent on having a better understanding of teachers' views. An answer was sought to the following research questions in this study:

1. What are the mean values of teachers' NOS conceptions?

2. Is there a statistically significant difference among the mean values of teachers' NOS conceptions with respect to their teaching disciplines?

3. Is there a statistically significant difference among the mean values of teachers' NOS conceptions with respect to their genders?

4. Is there a statistically significant difference among the mean values of teachers' NOS conceptions with respect to their education levels?

5. Is there a statistically significant difference among the mean values of teachers' NOS conceptions with respect to their teaching experiences?

6. Is there a statistically significant difference among the mean values of teachers' NOS conceptions with respect to their regional work locations?

\section{Research Design}

This research study was conducted adopting the survey research methodology. Survey research is one of the most prominent representatives of quantitative research and used widely in educational research studies to identify the general characteristics of a population about a specific topic at hand [21]. In survey research, the opinions of a sample of people collected in a form of self-report data are aimed to be generalized to a larger population. Turkish science, physics and elementary teachers were determined as the target population of this study. However, the accessible population of the study was restricted to the science, physics and elementary teachers who decided to apply for an astronomy science summer camp. A cross-sectional survey was employed to collect data in this study. That is, the data were gathered only once in time from a sample of teachers. According to Ruane [57], cross-sectional survey research "captures information at one moment in time", which is analogous to "a snapshot freezes a moment in time". The views of teachers about the specific aspects of NOS were investigated in this research study. 


\subsection{Research Context}

The data in this study was collected from teachers who were willing to participate in an astronomy science summer camp project sponsored by the Scientific and Technological Research Council of Turkey. A total of 647 applicant teachers completed the online version of a questionnaire instrument about NOS concepts (detailed information about the instrument is provided in the following section). The application was open to the public school teachers working in any part of Turkey. The data was obtained from physics, science and elementary teachers due to the fact that they were the only ones eligible to apply to the camp program. Table 1 displays the demographic information of the respondent teachers.

\subsection{Data Collection and Analysis}

An instrument entitled "Scientific Epistemological Views Questionnaire" was used in this research study to collect the data from the teachers. The questionnaire instrument developed originally by Liu and Tsai [45] was adapted to Turkish language in this study. It was translated to Turkish language by the author. The accuracy and the appropriateness of the translation were reviewed by two bilingual scholars in Turkish and English languages. Based on their suggestions, some corrections were made on the items in the instrument to improve their readability and comprehension.

The original questionnaire instrument consisted of a total of 25 items structured under the following five aspects of NOS: the role of social negotiation (SN), the invented and creative nature of science (IC), the theory-laden exploration
(TL), the cultural impacts (CI), and the changing and tentative feature of science knowledge (CT). The items in the questionnaire were designed in a Likert scale format with five levels of responses ranging from 'strongly agree' to 'strongly disagree'.

Some of the psychometric properties of the instrument were investigated to ensure its validity and reliability. Construct validity of the instrument was explored using "Principle Component Analysis" approach. Kaiser-Meyer-Olkin (KMO) as a measure of sampling adequacy to conduct the Principle Component Analysis was obtained as 0.699 . The higher value of this result than 0.5 indicated that the number of respondent teachers in the study were large enough to perform the Principle Component Analysis [66]. According to Bartlett's Test of Sphericity [ $\chi^{2}$ $(136)=1416.503, p<0.001]$, the correlations between the items in the instrument were found to be significantly large to conduct the Principle Component Analysis. A total of five factors having eigenvalues higher than 1 were extracted according to Kaiser's criterion of 1. Visual inspection of the scree plot also confirmed the five factorial structure of the instrument. $50.1 \%$ of the total variance in the instrument was explainable by these five factors. Factor 1, factor 2, factor 3, factor 4 and factor 5 were responsible respectively for $7.72 \%$, $17.67 \%, 7.18 \%, 8.45 \%$ and $9.10 \%$ of the total variance. Items with factor loadings lower than 0.40 , which explains less than $16 \%$ of the variance in a specific factor, were omitted from the instrument. Therefore, a total of seventeen items dispersed into the five factors were kept in the instrument. Table 2 illustrates the retained items in the instrument with their corresponding factor loadings.

Table 1. Demographic Information of the Respondent Teachers

\begin{tabular}{|c|c|c|c|c|c|c|c|}
\hline $\begin{array}{c}\text { Teaching } \\
\text { Discipline }\end{array}$ & Elementary & Physics & Science & & & \\
\hline $\mathbf{N}$ & 348 & 62 & 237 & & & & \\
\hline Gender & Female & Male & & & & & \\
\hline $\mathbf{N}$ & 260 & 387 & & & & & \\
\hline $\begin{array}{c}\text { Education } \\
\text { Level }\end{array}$ & Bachelor's & Master's & & & & & \\
\hline $\mathbf{N}$ & 580 & 67 & & & & & \\
\hline $\begin{array}{c}\text { Teaching } \\
\text { Experience }\end{array}$ & $0<\mathrm{x} \leq 5$ & $5<\mathrm{x} \leq 10$ & $10<\mathrm{x} \leq 15$ & $15<\mathrm{x} \leq 20$ & $20<\mathrm{x}$ & & \\
\hline $\mathbf{N}$ & 185 & 177 & 109 & 115 & 61 & & SE. Anatolia \\
\hline $\begin{array}{c}\text { Regional } \\
\text { Locations }\end{array}$ & Aegean & Black Sea & E. Anatolia & Marmara & M. Anatolia & Mediterranean & 118 \\
\hline $\mathbf{N}$ & 63 & 79 & 52 & 125 & 117 & 93 & . \\
\hline
\end{tabular}


Table 2. Factor Loadings of the Items in the Instrument

\begin{tabular}{|c|c|c|c|c|c|c|c|}
\hline Items & $\begin{array}{c}\text { Factor } 1 \\
\text { (SN) }\end{array}$ & $\begin{array}{c}\text { Factor } 2 \\
\text { (IC) }\end{array}$ & $\begin{array}{c}\text { Factor } 3 \\
\text { (TL) }\end{array}$ & $\begin{array}{c}\text { Factor } 4 \\
\text { (CI) }\end{array}$ & $\begin{array}{c}\text { Factor } 5 \\
\text { (CT) }\end{array}$ & Eigenvalues & $\%$ of Variance \\
\hline Item 03 & 0.648 & & & & & \multirow{3}{*}{1.313} & \multirow{3}{*}{7.722} \\
\hline Item 06 & 0.748 & & & & & & \\
\hline Item 07 & 0.720 & & & & & & \\
\hline Item 08 & & 0.644 & & & & \multirow{4}{*}{3.004} & \multirow{4}{*}{17.671} \\
\hline Item 09 & & 0.674 & & & & & \\
\hline Item 10 & & 0.722 & & & & & \\
\hline Item 11 & & 0.635 & & & & & \\
\hline Item 14 & & & 0.708 & & & \multirow{2}{*}{1.221} & \multirow{2}{*}{7.180} \\
\hline Item 15 & & & 0.735 & & & & \\
\hline Item 16 & & & & 0.572 & & \multirow{3}{*}{1.436} & \multirow{3}{*}{8.446} \\
\hline Item 18 & & & & 0.733 & & & \\
\hline Item 19 & & & & 0.692 & & & \\
\hline Item 20 & & & & & 0.537 & \multirow{5}{*}{1.547} & \multirow{5}{*}{9.102} \\
\hline Item 21 & & & & & 0.414 & & \\
\hline Item 23 & & & & & 0.439 & & \\
\hline Item 24 & & & & & 0.721 & & \\
\hline Item 25 & & & & & 0.693 & & \\
\hline
\end{tabular}

Table 3. Cronbach Alpha Reliability Coefficients of the Factors

\begin{tabular}{|c|c|c|}
\hline \multirow{2}{*}{ Aspects of NOS } & \multicolumn{2}{c|}{ Cronbach Alpha Reliability Coefficients } \\
\cline { 2 - 3 } & Original Instrument & Adapted Instrument \\
\hline Factor 1: The role of social negotiation (SN) & 0.75 & 0.64 \\
\hline Factor 2: The invented and creative nature of science (IC) & 0.56 & 0.62 \\
\hline Factor 3: The theory-laden exploration (TL) & 0.56 & 0.52 \\
\hline Factor 4: The cultural impacts (CI) & 0.56 & 0.54 \\
\hline Factor 5: The changing and tentative feature of science knowledge (CT) & 0.65 & 0.58 \\
\hline Overall: The Instrument & 0.76 & 0.67 \\
\hline
\end{tabular}

Internal consistency of the instrument was determined through Cronbach Alpha reliability coefficients calculated for each one of the five factors in the instrument. The overall value of the reliability coefficient of the original instrument had been found to be 0.76 by Liu and Tsai [45]. The reliability coefficient of the adapted version of the instrument was calculated as 0.67 . The values of the reliability coefficients for original and adapted versions of the instrument are presented in Table 3.

In the literature, 0.5 is generally acknowledged by many scholars to be the threshold for acceptable values of Cronbach Alpha Reliability Coefficient [11, 22, 40, 56]. None of the figures in Table 3 is less than the threshold value, which might be attributed to the internally consistent structure of the items in the sub-dimensions of the instrument. In addition, the overall value of the reliability coefficient (0.67) signifies the internal consistency of the instrument used in this study.

Due to the online nature of the instrument, the responses given by the teachers to the Likert-type items in the instrument were scored automatically by the system and stored as a Microsoft Excel document. While the responses 'strongly agree' were assigned 5 points, the responses 'strongly disagree' were given 1 point. The two items worded negatively in the sub-dimension "the theory-laden exploration (TL)" were scored in a reverse way. The analyses of the mean scores of the teachers with respect to their teaching majors, genders, education level, teaching experience and regional locations of their schools were made using MANOVA statistical test. Each specific sub-dimension of the instrument was treated as a dependent variable in MANOVA statistical analysis.

\section{Study Results}

In this section of the paper, the specific findings of the study are presented in organized tables. Starting with the first one, each one of the research questions is addressed in the following paragraphs. The first research question inquiries into the mean scores of teachers' NOS conceptions. Table 4 
displays the relevant information about the mean scores of the teachers for each specific sub-dimension of the instrument.

Table 4. Overall Mean Scores of the Teachers' NOS Conceptions

\begin{tabular}{|l|c|c|c|}
\hline \multicolumn{1}{|c|}{ Aspects of NOS } & N & Mean & SD \\
\hline The role of social negotiation (SN) & 647 & 4.601 & 0.469 \\
\hline $\begin{array}{l}\text { The invented and creative nature of } \\
\text { science (IC) }\end{array}$ & 647 & 4.435 & 0.563 \\
\hline The theory-laden exploration (TL) & 647 & 3.079 & 0.880 \\
\hline The cultural impacts (CI) & 647 & 3.888 & 0.797 \\
\hline $\begin{array}{l}\text { The changing and tentative feature of } \\
\text { science knowledge (CT) }\end{array}$ & 647 & 4.200 & 0.500 \\
\hline
\end{tabular}

According to Table 4, the participant teachers received the highest mean score $(\mathrm{M}=4.601)$ in the following sub-dimension of the instrument: the role of social negotiation $(\mathrm{SN})$. On the other hand, the lowest mean score $(M=3.079)$ was obtained by the teachers in the following aspect of NOS: the theory-laden exploration (TL). A careful inspection of Table 4 reveals that the mean scores of the teachers in specific aspects of NOS range from 'moderate' to 'high' level. The teachers achieved 'low' scores in none of the aspects of NOS.

The second research question was posed to determine the effect of the teaching disciplines of the teachers on their NOS conceptions. According to MANOVA statistical test result, 'teaching discipline' variable yielded a statistically significant multivariate effect on the mean scores of the teachers $[F(12,1278)=3.312, p=0.001$; Wilks' $\lambda=0.941$; $\left.\eta_{\mathrm{p}}{ }^{2}=0.03\right]$. Table 5 exhibits the corresponding values of the univariate test statistics to each one of the specific aspects of NOS.

The figures in Table 5 illustrate that the mean scores of elementary, physics and science teachers are significantly different from one another in the following four aspects of NOS: the role of social negotiation (SN), the invented and creative nature of science (IC), the theory-laden exploration (TL), and the changing and tentative feature of science knowledge (CT). Post-hoc comparisons of the mean scores indicate that the statistically significant difference favors science teachers over elementary teachers in these four aspects of NOS. In 'the theory-laden exploration (TL)' sub-dimension of the instrument, elementary teachers scored significantly higher than their physics colleagues. According to Cohen [15], any value of 'partial $\eta^{2}$ ' between 0.01 and 0.06 corresponds to a small effect size. All values of 'partial $\eta^{2}$ ' in this study are less than 0.06 , which suggests that the magnitude of the differences between the mean scores of the teachers with different teaching disciplines is relatively small. Although there exist statistically significant differences between the mean scores of the teachers from different teaching disciplines, the practical meaning of these significant differences should be discussed further due to the relatively small values of effect sizes.

Table 5. Univariate Test Statistics of Teachers' Mean Scores with Respect to Their Teaching Disciplines

\begin{tabular}{|c|c|c|c|c|c|c|c|}
\hline Aspects of NOS & $\begin{array}{c}\text { Teaching } \\
\text { Discipline }\end{array}$ & $\mathrm{N}$ & Mean & SD & Univariate F-Statistics & Partial $\eta_{\mathrm{p}}^{2}$ & Sig. Diff. \\
\hline \multirow{3}{*}{ Factor-1 (SN) } & PT & 62 & 4.581 & 0.490 & \multirow{3}{*}{$F(2,644)=2.996 ; p=0.051$} & \multirow{3}{*}{0.009} & \multirow{3}{*}{ ST-ET* } \\
\hline & ST & 237 & 4.660 & 0.434 & & & \\
\hline & ET & 348 & 4.565 & 0.485 & & & \\
\hline \multirow{3}{*}{ Factor-2 (IC) } & PT & 62 & 4.423 & 0.529 & \multirow{3}{*}{$\mathrm{F}(2,644)=6.416 ; \mathrm{p}=0.002$} & \multirow{3}{*}{0.02} & \multirow{3}{*}{ ST-ET** } \\
\hline & ST & 237 & 4.537 & 0.496 & & & \\
\hline & ET & 348 & 4.369 & 0.602 & & & \\
\hline \multirow{3}{*}{ Factor-3 (TL) } & PT & 62 & 2.718 & 0.808 & \multirow{3}{*}{$\mathrm{F}(2,644)=6.680 ; \mathrm{p}=0.001$} & \multirow{3}{*}{0.02} & \multirow{3}{*}{$\begin{array}{l}\text { ST-PT** } \\
\text { ET-PT** }\end{array}$} \\
\hline & ST & 237 & 3.173 & 0.842 & & & \\
\hline & ET & 348 & 3.080 & 0.904 & & & \\
\hline \multirow{3}{*}{ Factor-4 (CI) } & PT & 62 & 3.839 & 0.763 & \multirow{3}{*}{$F(2,644)=0.428 ; p=0.652$} & \multirow{3}{*}{0.001} & \\
\hline & ST & 237 & 3.864 & 0.797 & & & \\
\hline & ET & 348 & 3.915 & 0.804 & & & \\
\hline \multirow{3}{*}{ Factor-5 (CT) } & $\mathrm{PT}$ & 62 & 4.177 & 0.495 & \multirow{3}{*}{$F(2,644)=4.793 ; p=0.009$} & \multirow{3}{*}{0.015} & \multirow{3}{*}{ ST-ET** } \\
\hline & ST & 237 & 4.279 & 0.477 & & & \\
\hline & ET & 348 & 4.151 & 0.512 & & & \\
\hline
\end{tabular}

*significant at $\alpha=0.05$

**significant at $\alpha=0.01$

PT=Physics Teachers, ST=Science Teachers, and ET=Elementary Teachers 
The third research question in the study aims to ascertain whether the gender of the teachers makes any difference on their NOS conceptions. No statistically significant multivariate difference was found with respect to the genders of the teachers $[\mathrm{F}(6,640)=0.679, \mathrm{p}=0.667$; Wilks' $\lambda=0.994$; Partial $\left.\eta^{2}=0.006\right]$. The values of univariate test statistics in each one of the specific aspects of NOS are presented in Table 6

Considering the insignificant results in Table 6 , gender of the teachers seems to be an ineffective variable on their NOS conceptions.

The fourth research question in the study is interested in exploring the effect of education levels of the teachers on their NOS conceptions. The multivariate analysis of the mean scores of the teachers with respect to their education levels produced an insignificant result $[\mathrm{F}(6,640)=0.207$, $\mathrm{p}=0.667$; Wilks' $\lambda=0.974$; Partial $\left.\eta^{2}=0.002\right]$. Table 7 provides the values of univariate statistical tests together with the mean scores of the teachers with respect to their education levels.

According to Table 7 , no statistically significant difference is existent between the mean scores of the teachers holding bachelor's and master's degrees. This result implies that the NOS conceptions of the teachers have nothing to do with their education levels.

Table 6. Univariate Test Statistics of Teachers' Mean Scores with Respect to Their Genders

\begin{tabular}{|c|c|c|c|c|c|}
\hline Aspects of NOS & Gender & $\mathrm{N}$ & Mean & $\mathrm{SD}$ & Univariate F-Statistics \\
\hline \multirow{2}{*}{ Factor-1 (SN) } & $\mathrm{F}$ & 260 & 4.605 & 0.465 & \multirow{2}{*}{$F(1,645)=0.039 ; p=0.843$} \\
\hline & M & 387 & 4.598 & 0.472 & \\
\hline \multirow{2}{*}{ Factor-2 (IC) } & $\mathrm{F}$ & 260 & 4.467 & 0.523 & \multirow{2}{*}{$F(1,645)=1.388 ; p=0.239$} \\
\hline & M & 387 & 4.414 & 0.589 & \\
\hline \multirow{2}{*}{ Factor-3 (TL) } & $\mathrm{F}$ & 260 & 3.113 & 0.811 & \multirow{2}{*}{$F(1,645)=0.642 ; p=0.423$} \\
\hline & M & 387 & 3.057 & 0.925 & \\
\hline \multirow{2}{*}{ Factor-4 (CI) } & $\mathrm{F}$ & 260 & 3.887 & 0.849 & \multirow{2}{*}{$F(1,645)=0.002 ; p=0.967$} \\
\hline & M & 387 & 3.890 & 0.762 & \\
\hline \multirow{2}{*}{ Factor-5 (CT) } & $\mathrm{F}$ & 260 & 4.205 & 0.495 & \multirow{2}{*}{$\mathrm{F}(1,645)=0.032 ; \mathrm{p}=0.858$} \\
\hline & M & 387 & 4.197 & 0.505 & \\
\hline
\end{tabular}

$\mathrm{F}=$ Female, $\mathrm{M}=$ Male

Table 7. Univariate Test Statistics of Teachers' Mean Scores with Respect to Their Education Levels

\begin{tabular}{|c|c|c|c|c|c|}
\hline Aspects of NOS & $\begin{array}{c}\text { Education } \\
\text { Level }\end{array}$ & $\mathrm{N}$ & Mean & SD & Univariate F-Statistics \\
\hline \multirow{2}{*}{ Factor-1 (SN) } & $\mathrm{BD}$ & 580 & 4.605 & 0.470 & \multirow{2}{*}{$\mathrm{F}(1,645)=0.379 ; \mathrm{p}=0.539$} \\
\hline & MD & 67 & 4.568 & 0.464 & \\
\hline \multirow{2}{*}{ Factor-2 (IC) } & $\mathrm{BD}$ & 580 & 4.433 & 0.572 & \multirow{2}{*}{$F(1,645)=0.092 ; p=0.762$} \\
\hline & MD & 67 & 4.455 & 0.484 & \\
\hline \multirow{2}{*}{ Factor-3 (TL) } & $\mathrm{BD}$ & 580 & 3.078 & 0.890 & \multirow{2}{*}{$F(1,645)=0.010 ; p=0.922$} \\
\hline & MD & 67 & 3.090 & 0.802 & \\
\hline \multirow{2}{*}{ Factor-4 (CI) } & $\mathrm{BD}$ & 580 & 3.896 & 0.806 & \multirow{2}{*}{$F(1,645)=0.397 ; p=0.529$} \\
\hline & MD & 67 & 3.831 & 0.719 & \\
\hline \multirow{2}{*}{ Factor-5 (CT) } & $\mathrm{BD}$ & 580 & 4.202 & 0.501 & \multirow{2}{*}{$F(1,645)=0.069 ; p=0.793$} \\
\hline & MD & 67 & 4.185 & 0.501 & \\
\hline
\end{tabular}

$\mathrm{BD}=$ Bachelor's Degree and MD=Master's Degree 
Investigating the effect of the teaching experience on the NOS conceptions of the teachers is the central purpose of the fifth research question in the study. The multivariate analysis of the mean scores of the teachers with respect to their teaching experience produced a statistically significant result $[\mathrm{F}(24,2223.438)=3.124, \mathrm{p}=0.001$; Wilks' $\lambda=0.891$; Partial $\left.\eta^{2}=0.029\right]$. The information about the mean scores of the teachers in each specific aspect of NOS and their corresponding values of the univariate test statistics are available in Table 8 .

The figures in Table 8 indicate that there is a significant difference only in one of the aspects of NOS with respect to the teaching experiences of the teachers: The theory-laden exploration (TL). It appears that less experienced teachers scored significantly higher than their more experienced colleagues in this very specific aspect of NOS. As the years of teaching experience increased in this aspect of NOS, the mean scores of the teachers tended to decrease systematically. In this sub-dimension of the instrument, teachers with less than five years of teaching experience significantly outperformed the more experienced teachers.

Table 8. Univariate Test Statistics of Teachers' Mean Scores with Respect to Their Teaching Experiences

\begin{tabular}{|c|c|c|c|c|c|c|c|}
\hline Aspects of NOS & $\begin{array}{c}\text { Teaching } \\
\text { Experience }\end{array}$ & $\mathrm{N}$ & Mean & SD & $\begin{array}{l}\text { Univariate } \\
\text { F-Statistics }\end{array}$ & Partial $\eta_{p}^{2}$ & Sig. Diff. \\
\hline \multirow{5}{*}{ Factor-1 (SN) } & $0<x \leq 5$ & 185 & 4.665 & 0.449 & \multirow{5}{*}{$\begin{array}{c}\mathrm{F}(4,642)=1.467 \\
\mathrm{p}=0.210\end{array}$} & \multirow{5}{*}{0.009} & \\
\hline & $5<x \leq 10$ & 177 & 4.575 & 0.448 & & & \\
\hline & $10<x \leq 15$ & 109 & 4.578 & 0.517 & & & \\
\hline & $15<x \leq 20$ & 115 & 4.600 & 0.425 & & & \\
\hline & $20<x$ & 61 & 4.525 & 0.563 & & & \\
\hline \multirow{5}{*}{ Factor-2 (IC) } & $0<x \leq 5$ & 185 & 4.476 & 0.572 & \multirow{5}{*}{$\begin{array}{c}\mathrm{F}(2,644)=1.372 \\
\mathrm{p}=0.242\end{array}$} & \multirow{5}{*}{0.008} & \\
\hline & $5<x \leq 10$ & 177 & 4.470 & 0.541 & & & \\
\hline & $10<x \leq 15$ & 109 & 4.392 & 0.545 & & & \\
\hline & $15<x \leq 20$ & 115 & 4.343 & 0.600 & & & \\
\hline & $20<x$ & 61 & 4.463 & 0.557 & & & \\
\hline \multirow{5}{*}{ Factor-3 (TL) } & $0<x \leq 5$ & 185 & 3.397 & 0.842 & \multirow{5}{*}{$\begin{array}{c}\mathrm{F}(2,644)=13.405 \\
\mathrm{p}=0.001\end{array}$} & \multirow{5}{*}{0.077} & \multirow{5}{*}{$\begin{array}{c}(0<x \leq 5)-(5<x \leq 10)^{*} \\
(0<x \leq 5)-(10<x \leq 15)^{* *} \\
(0<x \leq 5)-(15<x \leq 20)^{* *} \\
(0<x \leq 5)-(20<x)^{* *} \\
(5<x \leq 10)-(15<x \leq 20)^{*} \\
(5<x \leq 10)-(20<x)^{* *}\end{array}$} \\
\hline & $5<x \leq 10$ & 177 & 3.119 & 0.841 & & & \\
\hline & $10<x \leq 15$ & 109 & 3.000 & 0.861 & & & \\
\hline & $15<x \leq 20$ & 115 & 2.796 & 0.915 & & & \\
\hline & $20<x$ & 61 & 2.680 & 0.730 & & & \\
\hline \multirow{5}{*}{ Factor-4 (CI) } & $0<x \leq 5$ & 185 & 3.907 & 0.839 & \multirow{5}{*}{$\begin{array}{c}F(2,644)=0.456 \\
p=0.768\end{array}$} & \multirow{5}{*}{0.003} & \\
\hline & $5<x \leq 10$ & 177 & 3.921 & 0.751 & & & \\
\hline & $10<x \leq 15$ & 109 & 3.848 & 0.788 & & & \\
\hline & $15<x \leq 20$ & 115 & 3.907 & 0.824 & & & \\
\hline & $20<x$ & 61 & 3.781 & 0.779 & & & \\
\hline \multirow{5}{*}{ Factor-5 (CT) } & $0<x \leq 5$ & 185 & 4.253 & 0.448 & \multirow{5}{*}{$\begin{array}{c}\mathrm{F}(2,644)=2.234 \\
\mathrm{p}=0.064\end{array}$} & \multirow{5}{*}{0.014} & \\
\hline & $5<x \leq 10$ & 177 & 4.235 & 0.503 & & & \\
\hline & $10<x \leq 15$ & 109 & 4.187 & 0.519 & & & \\
\hline & $15<x \leq 20$ & 115 & 4.089 & 0.559 & & & \\
\hline & $20<x$ & 61 & 4.174 & 0.473 & & & \\
\hline
\end{tabular}

*significant at $\alpha=0.05$

$* *$ significant at $\alpha=0.01$ 
Table 9. Univariate Test Statistics of Teachers' Mean Scores with Respect to Their Regional Work Locations

\begin{tabular}{|c|c|c|c|c|c|c|c|}
\hline Aspects of NOS & Regional Locations & $\mathrm{N}$ & Mean & SD & Univariate F-Statistics & Partial $\eta_{\mathrm{p}}^{2}$ & Sig. Diff. \\
\hline \multirow{7}{*}{ Factor-1 (SN) } & Marmara & 125 & 4.584 & 0.530 & \multirow{7}{*}{$\begin{array}{c}F(6,640)=1.439 \\
\quad p=0.197\end{array}$} & \multirow{7}{*}{0.013} & \\
\hline & Aegean & 63 & 4.698 & 0.353 & & & \\
\hline & Black Sea & 79 & 4.498 & 0.526 & & & \\
\hline & M. Anatolia & 117 & 4.638 & 0.426 & & & \\
\hline & Mediterranean & 93 & 4.606 & 0.384 & & & \\
\hline & E. Anatolia & 52 & 4.654 & 0.428 & & & \\
\hline & SE. Anatolia & 118 & 4.571 & 0.523 & & & \\
\hline \multirow{7}{*}{ Factor-2 (IC) } & Marmara & 125 & 4.510 & 0.526 & \multirow{7}{*}{$\begin{array}{c}\mathrm{F}(6,640)=0.717 \\
\mathrm{p}=0.636\end{array}$} & \multirow{7}{*}{0.007} & \\
\hline & Aegean & 63 & 4.377 & 0.641 & & & \\
\hline & Black Sea & 79 & 4.383 & 0.562 & & & \\
\hline & M. Anatolia & 117 & 4.442 & 0.525 & & & \\
\hline & Mediterranean & 93 & 4.409 & 0.602 & & & \\
\hline & E. Anatolia & 52 & 4.389 & 0.650 & & & \\
\hline & SE. Anatolia & 118 & 4.458 & 0.527 & & & \\
\hline \multirow{7}{*}{ Factor-3 (TL) } & Marmara & 125 & 3.012 & 0.792 & \multirow{7}{*}{$\begin{array}{c}F(6,640)=3.674 \\
p=0.001\end{array}$} & \multirow{7}{*}{0.033} & \multirow{7}{*}{$\begin{array}{c}\text { E. } \\
\text { Anatolia-Mediterranean* } \\
\text { SE. } \\
\text { Anatolia-Mediterranean** }\end{array}$} \\
\hline & Aegean & 63 & 3.032 & 0.718 & & & \\
\hline & Black Sea & 79 & 3.019 & 0.998 & & & \\
\hline & M. Anatolia & 117 & 3.026 & 0.949 & & & \\
\hline & Mediterranean & 93 & 2.860 & 0.832 & & & \\
\hline & E. Anatolia & 52 & 3.327 & 0.933 & & & \\
\hline & SE. Anatolia & 118 & 3.335 & 0.850 & & & \\
\hline \multirow{7}{*}{ Factor-4 (CI) } & Marmara & 125 & 3.904 & 0.846 & \multirow{7}{*}{$\begin{array}{c}\mathrm{F}(6,640)=0.439 \\
\mathrm{p}=0.853\end{array}$} & \multirow{7}{*}{0.004} & \\
\hline & Aegean & 63 & 3.963 & 0.797 & & & \\
\hline & Black Sea & 79 & 3.818 & 0.769 & & & \\
\hline & M. Anatolia & 117 & 3.895 & 0.784 & & & \\
\hline & Mediterranean & 93 & 3.814 & 0.805 & & & \\
\hline & E. Anatolia & 52 & 3.865 & 0.820 & & & \\
\hline & SE. Anatolia & 118 & 3.944 & 0.770 & & & \\
\hline \multirow{7}{*}{ Factor-5 (CT) } & Marmara & 125 & 4.267 & 0.536 & \multirow{7}{*}{$\begin{array}{c}F(6,640)=0.688 \\
\quad p=0.660\end{array}$} & \multirow{7}{*}{0.006} & \\
\hline & Aegean & 63 & 4.210 & 0.456 & & & \\
\hline & Black Sea & 79 & 4.192 & 0.516 & & & \\
\hline & M. Anatolia & 117 & 4.207 & 0.519 & & & \\
\hline & Mediterranean & 93 & 4.140 & 0.469 & & & \\
\hline & E. Anatolia & 52 & 4.154 & 0.454 & & & \\
\hline & SE. Anatolia & 118 & 4.192 & 0.501 & & & \\
\hline
\end{tabular}

*significant at $\alpha=0.05$

$* *$ significant at $\alpha=0.01$

The sixth research question in the study concentrates on the effect of the regional work locations of the teachers on their NOS conceptions. MANOVA statistical test revealed that there was an overall significant difference between the mean scores of the teachers with respect to their regional work locations $[\mathrm{F}(36,2791.241)=1.495, \mathrm{p}=0.03$; Wilks' $\lambda=0.92$; Partial $\left.\eta^{2}=0.014\right]$. The mean scores of the teachers and the univariate test statistics with respect to the regional work locations of the teachers are presented in Table 9.

In Table 9, the statistically significant difference was detected only in one aspect of NOS: the theory-laden exploration (TL). In this aspect of NOS, the lowest mean score (2.860) was obtained by the teachers working in Mediterranean region. The mean scores of the teachers in Mediterranean region were significantly less than the ones in E. Anatolia and SE. Anatolia regions.

\section{Conclusions and Implications}

The mean scores of the teachers in five specific aspects of 
NOS range from 3.079 to 4.601 . The respondent teachers obtained the lowest mean score $(M=3.079)$ in 'the theory-laden exploration (TL)' aspect of NOS. They attained the highest mean score $(\mathrm{M}=4.601)$ in 'the role of social negotiation (SN)' sub-dimension of the instrument. The corresponding ranks of these mean scores vary from 'medium' to 'high' level of understanding of NOS concepts. This result stands, to some extent, at odds with an ample number of the research studies reporting the inadequate understanding of the teachers about NOS concepts [27, 55, 65]. The relatively higher values of the mean scores of the respondent teachers in this study indicated that they had grasped a certain level of understanding about the specific aspects of NOS. Teachers do not necessarily hold fragile conceptions about all of the aspects of NOS. That is, whereas they have a better comprehension of the select aspects of NOS, they develop a less adequate understanding of certain NOS concepts. Therefore, making holistic generalizations about teachers' understanding of NOS concepts might result in an underestimation or overestimation of their cognitive structures about the specific dimensions of NOS concepts. Determining the specific aspects of NOS in which teachers need support the most is crucially important for developing the appropriate strategies in educating knowledgeable teachers about NOS concepts.

According to the findings of the study, teaching discipline appeared to be an influential demographic variable which made a statistically significant difference in all but one aspect of NOS. Except one aspect of NOS (The Cultural Impacts), science teachers outperformed their colleagues in elementary and physics disciplines. It is not a secret that both science and physics teachers in their undergraduate education and teaching profession are engaged with science content more than elementary teachers. However, having a stronger background in science is not necessarily synonymous with developing a higher level of understanding about NOS concepts [50]. The case might be strengthened by a comparison of the physics and elementary teachers in this study. None of the figures yielded a statistically significant difference in favor of physics teachers. On the contrary, the elementary teachers scored statistically significantly higher than the physics teachers in "the Theory-laden Explorations" aspect of NOS. In terms of the role of having different theoretical perspectives in the production of the scientific knowledge, the thoughts of the physics teachers were more conservative than the elementary teachers. In other words, the physics teachers refrained more from accepting the idea that the preexisting perspectives held by scientists play a significant role in shaping the scientific knowledge. This result seems to be plausible considering the positivistic education, which conceptualizes the science as an objective source of knowledge, given to the physics teachers in their undergraduate education. The relatively higher performance of the science teachers in the study might be attributed to their engagement not only with science content but also with NOS concepts in their undergraduate years. In fact, several criticisms in the literature are directed to the insufficient NOS education given to the teacher candidates in teacher education programs worldwide. It is pretty usual that teacher candidates in many universities graduate from their programs without attending even a single NOS course. One of the questions posed to the participant teachers in this study inquired in whether they had received any training previously in NOS concepts. Only $13 \%$ of the responses given by teachers to this question were positive. While this figure tells us a little about the exact nature of teachers' NOS training based on their self-report data, it reveals a lot about teachers' lack of the formal education in NOS concepts. For the last few years, prospective science teachers in Turkish universities have been enrolling a course completely dedicated to NOS concepts in their third year of study. However, neither prospective physics teachers nor their elementary peers are offered a NOS course in their program of studies. The chances were quite slim that the physics and elementary teachers in this study had attended any NOS course in their undergraduate education. It seems that they attained a satisfactory performance in this study without having a proper education about NOS concepts in their undergraduate education. In this study, their 'informed' conceptions of NOS in select aspects of NOS might be explained primarily by their preexisting personal epistemological beliefs. There are several research studies in the literature indicating the link between the personal epistemological beliefs and NOS conceptions of teachers [13, 48]. In parallel to the substantial promotion of constructivist approach in the education system lately, the postmodern interpretations of science started to find more space in teacher education programs. However, this still does not abolish teacher candidates' need for a separate NOS course in teacher education programs.

With respect to gender, statistically significant difference was detected between male and female teachers in none of the aspects of NOS. For a long time, there has been a debate about the gender gap in science, which usually means the unequal representation of men and women in science-related professions $[7,9,10,23,35,64]$. Despite the fact that no achievement difference exists between boys and girls in school science, girls seem to be less interested than boys in pursuing a professional career in STEM (Science, Technology, Engineering, and Mathematics) fields [28, 36, 52]. Whereas no single factor by itself is successful enough to provide a satisfying explanation for gender inequality in science as a historic problem for many countries all over the world, attitudes towards science take definitely one of the leading roles in career decisions of students. There are a numerous number of research studies reporting more positive attitudes of boys towards science than girls in the literature $[8,16,23,34,52]$. Students' attitudes towards science are shaped in part by their personal views of science $[14,30]$. Students hold a variety of stereotypical and inaccurate images of science and scientists [14]. For instance, the research studies conducted using Draw-A-Scientist Test 
(DAST) indicate that students generally conceptualize scientists stereotypically as males working in a laboratory with eyeglasses and white lab coats $[12,20,53,63,67]$. Preceding discussions reveal that gender is an important variable when it comes to identifying individuals' conceptions of science. However, gender made no significant effect on teachers' views of science in this research study. Could this result have anything to do with the participant female teachers who have already chosen a teaching career in physics and science disciplines? Do we get the similar results in comparison to female elementary teachers? A Multivariate Analysis of Variance (MANOVA) was carried out to examine whether there exists a significant interaction effect between gender and teaching discipline variables. The result yielded no statistically significant multivariate interaction effect $[\mathrm{F}(10,1274)=0.779$, $\mathrm{p}=0.649$; Wilks' $\lambda=0.98$; Partial $\left.\eta^{2}=0.006\right]$, which confirmed the ineffectual status of gender on NOS conceptions of the teachers in this study.

The statistical analysis of the teachers' responses with respect to their education level revealed no significant result. Therefore, having a higher education degree was unhelpful to teachers to gain a better understanding of NOS concepts. Like many undergraduate teacher education programs, Master of Science (MS) programs are usually deprived of a specific NOS course. An elective philosophy of science course is offered to students in some of the science education MS programs. Therefore, majority of the teachers in the study completed the MS degree programs without engaging in even a single course dedicated completely to NOS concepts.

Chief among a myriad of factors impacting academic growth of students is teacher effectiveness [31]. However, what characteristics of teachers make them more effective is one of the highly debated questions in education field. Teaching experience is pronounced in many research studies as an important variable in determining the effectiveness of teachers [33, 39]. While experienced teachers are considered as more effective in general than new teachers, the difference almost disappears after gaining a few years of teaching experience [25, 38]. Except one aspect of NOS, no statistically significant difference was detected in this study among the teachers with varied years of teaching experience. The teachers having a teaching experience of 0 to 5 years scored significantly higher than their more experienced colleagues in factor-3 (The theory-laden exploration). This result implies that the influence of scientists' preexisting conceptions on their scientific observations was acknowledged more by inexperienced teachers than their experienced colleagues. The personal epistemologies of the teachers might be given as a plausible explanation for this difference between inexperienced and experienced teachers in factor-3. In a research report published by OECD, new teachers in Turkey were found to be in favor of constructivist beliefs more than experienced ones [33]. In parallel to the recent standards in Turkish education system promoting the use of constructivist approach by teachers in their classrooms, teacher education programs have started to give more emphasis to educate teacher candidates with a constructivist perspective. For that reason, there was a higher probability of having completed a constructivist-oriented education in their undergraduate education by inexperienced teachers in this study. Due to the fact that constructivism asserts that one constructs his/her unique understanding of the world with the involvement of his/her prior knowledge, the theory-ladenness of the scientific observations is highly compatible with constructivist ideas. Therefore, the theory-ladenness of the observations is one of NOS concepts which are relatively easier to be acknowledged by teachers adopting the central tenets of constructivism.

People convey the social and cultural values of the geographic regions in which they live. It is probable that geographic regions having the peculiar traditions and customs are dominated by a specific ideological perspective which is more or less compatible with contemporary concepts of NOS. Therefore, it is plausible to expect that individuals from the same region are prone to share a common mindset. Could this be the case in terms of teachers' conceptions of NOS? Regional work locations of teachers made a significant difference in only one aspect of NOS. In factor-3 (The theory-laden exploration), the teachers working in East Anatolia and Southeast Anatolia regions received significantly higher scores than their colleagues working in Mediterranean region. This difference between teachers working in different regions of Turkey might be attributed primarily to their personal epistemologies. As discussed earlier, there are research findings in the literature that inexperienced teachers in Turkey support constructivist approach in their teaching practices more than experienced teachers [33]. Providing a comprehensive explanation to this situation is beyond the scope of this research study. However, one possible explanation is that new teachers start the teaching profession with idealism, yet the idealism gradually turns into realism as they face the realities of the education system. Beginner teachers in each year are appointed to their first regional work locations by the Turkish Ministry of Education. The chances of starting their first work experiences at a socioeconomically disadvantaged region are pretty high at the very early stages of their teaching careers. As they gain more experience in the profession, they tend to move another region having relatively higher socioeconomic status. This means that the density of new teachers is naturally higher in certain regions (e.g. East Anatolian Region and Southeast Anatolian Region). Working at a school located in Mediterranean Region usually demands having more experience in teaching profession. In this study, significant difference between the teachers in East and Southeast regions and the teachers in Mediterranean region is explained possibly by the higher density of inexperienced teachers working in East and Southeast regions. 


\section{REFERENCES}

[1] F. Abd-El-Khalick. Developing deeper understandings of nature of science: The impact of a philosophy of science course on preservice science teachers' views and instructional planning, International Journal of Science Education, Vol.27, No.1, 15-42, 2005.

[2] F. Abd-El-Khalick, N. G. Lederman. Improving science teachers' conceptions of nature of science: A critical review of the literature, International Journal of Science Education, Vol.22, No.7, 665-701, 2000.

[3] F. Abd-El-Khalick, V. L. Akerson. Learning as conceptual change: Factors mediating the development of preservice elementary teachers' views of nature of science, Science Education, Vol.88, 785-810, 2004.

[4] E. Aflalo. Advancing the perceptions of the nature of science (NOS): Integrating teaching the NOS in a science content course, Research in Science \& Technological Education, Vol.32, No.3, 298-317, 2014.

[5] N. U. Bautista, E. E. Schussler, S. M. Rybczynski. Instructional experiences of graduate assistants implementing explicit and reflective introductory biology laboratories, International Journal of Science Education, Vol.36, No.7, 1184-1209, 2014.

[6] R. L. Bell, B. K. Mulvey, J. L. Maeng. Outcomes of nature of science instruction along a context continuum: Preservice secondary science teachers' conceptions and instructional intentions, International Journal of Science Education, Vol.38, No.3, 493-520, 2016.

[7] J. C. Blickenstaff. Women and science careers: Leaky pipeline or gender filter?, Gender and Education, Vol.17, No.4, 369-386, 2005.

[8] N. W. Brickhouse, P. Lowery, K. Schultz. What kind of a girl does science? The construction of school science identities, Journal of Research in Science Teaching, Vol.37, No.5, 441-458, 2000.

[9] J. S. Brotman, F. M. Moore. Girls and science: A review of four themes in the science education literature, Journal of Research in Science Teaching, Vol.45, No.9, 971-1002, 2008.

[10] M. Caprile, E. Addis, C. Castano, I. Klinge, M. Larios, D. Meulders, S. Vazquez-Cupeiro. Meta-analysis of gender and science research: Synthesis report, European Union, Spain, 2012.

[11] C. Chacrapani. Statistics in market research, Arnold Publisher, London, 2004.

[12] D. W. Chambers. Stereotypic images of the scientist: The draw-a-scientist test, Science Education, Vol.67, No.2, 255-265, 1983.

[13] M. Cho, D. M. Lankford, D. J. Wescott. Exploring the relationships among epistemological beliefs, nature of science, and conceptual change in the learning of evolutionary theory, Evolution: Education and Outreach, Vol.4, No.2, 313-322, 2011

[14] V. Christidou. Interests, attitudes and images related to science: Combining students' voices with the voices of school science, teachers, and popular science, International Journal of Environmental \& Science Education, Vol.6, No.2, 141-159, 2011.
[15] J. Cohen. Statistical power analysis for the behavioral sciences, Routledge Academic, New York, 1988.

[16] E. A. Dare, G. H. Roehrig. If I had to do it, then I would: Understanding early middle school students' perceptions of physics and physics-related careers by gender, Physical Review Physics Education Research, Vol.12, 1-11, 2016.

[17] P. Dekkers, E. Mnisi. The nature of science: Do teachers have the understandings they are expected to teach, African Journal of Research in Mathematics, Science and Technology Education, Vol.7, No.1, 21-34, 2003.

[18] F. Deng, D. Chen, C. Tsai, C. S. Chai. Students' views of the nature of science: A critical review of research, Science Education, Vol.95, 961-999, 2011.

[19] J. T. Eflin, S. Glennan, G. Reisch. The nature of science: A perspective from the philosophy of science, Journal of Research in Science Teaching, Vol.36, No.1, 107-116, 1999.

[20] K. D. Finson. Drawing a scientist: What we do and do not know after fifty years of drawings, School Science and Mathematics, Vol.102, No.7, 335-345, 2002.

[21] J. R. Fraenkel, N. E. Wallen, H. H. Hyun. How to design and evaluate research in education, The McGraw-Hill Companies, New York, 2012.

[22] G. George, P. Mallery. SPSS for windows step by step: A simple guide and reference, 11.0 Update, Allyn and Bacon, Boston, MA, 2003

[23] S. Gilmartin, N. Denson, E. Li, A. Bryant, P. Aschbacher. Gender ratios in high school science departments: The effect of percent female faculty on multiple dimensions of students' science identities, Journal of Research in Science Teaching, Vol.44, No.7, 980-1009, 2007.

[24] R. Good, J. Shymansky. Nature-of-science literacy in benchmarks and standards: post-modern/relativist or modern/realist?, Science \& Education, Vol.10, 173-185, 2001.

[25] Hanover Research. Teacher experience and student achievement, Hanover Research, Arlington, VA, 2016.

[26] B. C. Herman, M. P. Clough, J. K. Olson. Teachers' nature of science implementation practices 2-5 years after having completed an intensive science education program, Science Education, Vol.97, No.2, 271-309, 2013

[27] B. C. Herman, M. P. Clough, J. K. Olson. Pedagogical reflections by secondary science teachers at different NOS implementation levels, Research in Science Education, Vol.45, No.4, 1-24, 2015.

[28] C. Hill, C. Corbett, A. S. Rose. Why so few? Women in science, technology, engineering, and mathematics, The American Association of University Women (AAUW), Washington, DC, 2010.

[29] D. Hodson. Towards scientific literacy: A teachers' guide to the history, philosophy and sociology of science, Sense Publishers, Rotterdam, The Netherlands, 2008.

[30] S. Hsiao-Ching. Gender and grade level differences in Taiwan students' stereotypes of science and scientists, Research in Science \& Technological Education, Vol.16, No.2, 125-135, 1998. 
[31] F. L. Huang, T. R. Moon. Is experience the best teacher? A multilevel analysis of teacher characteristics and student achievement in low performing schools, Educational Assessment, Evaluation and Accountability, Vol.21, 209-234, 2009.

[32] E. W. Jenkins. The nature of science in the school curriculum: The great survivor, Journal of Curriculum Studies, Vol.45, No.2, 132-151, 2013.

[33] B. Jensen, A. Sandoval-Hernandez, S. Knoll, E. J. Gonzalez. The experience of new teachers: Results from TALIS 2008, OECD Publishing, Paris, France, 2012.

[34] M. G. Jones, A. Howe, M. J. Rua. Gender differences in students' experiences, interests, and attitudes toward science and scientists, Science Education, Vol.84, 180-192, 2000.

[35] J. Kenway, A. Gough. Gender and science education in schools: A review 'with attitude', Studies in Science Education, Vol.31, 1-30, 1998.

[36] S. Kerger, R. Martin, M. Brunner. How can we enhance girls' interest in scientific topics?, British Journal of Educational Psychology, Vol.81, 606-628, 2011.

[37] R. Khishfe, N. Lederman. Teaching nature of science within a controversial topic: Integrated versus nonintegrated, Journal of Research in Science Teaching, Vol.43, No.4, 395- 418, 2006.

[38] J. King Rice. The impact of teacher experience: Examining the evidence and policy implications, National Center for Analysis of Longitudinal Data in Education Research, Washington, DC, 2010.

[39] T. Kini, A. Podolsky. Does teaching experience increase teacher effectiveness? A review of the research, Learning Policy Institute, Palo Alto, 2016.

[40] P. Kline. The handbook of psychological testing $\left(2^{\text {nd }} e d.\right)$, Routledge, London, 2000.

[41] N. G. Lederman. Nature of science: Past, present, and future. In S. K. Abell, N. G. Lederman (Eds.), Handbook of research on science education (pp.831-881), Lawrence Erlbaum Associates, Inc., Publishers, Mahwah, New Jersey, 2007.

[42] N. G. Lederman, F. Abd-El-Khalick, R. L. Bell, R. S. Schwartz. Views of nature of science questionnaire: Toward valid and meaningful assessment of learners' conceptions of nature of science, Journal of Research in Science Teaching, Vol.39, No.6, 497-521, 2002.

[43] N. G. Lederman, A. Antink, S. Bartos. Nature of science, scientific inquiry, and socio-scientific issues arising from genetics: A pathway to developing a scientifically literate citizenry, Science \& Education, Vol.23, 285-302, 2014.

[44] J. S. C. Leung, A. S. L. Wong, B. H. W. Yung. Evaluation of science in the media by non-science majors, International Journal of Science Education, Part B, 1-18, 2016.

[45] S. Liu, C. Tsai. Differences in the scientific epistemological views of undergraduate students, International Journal of Science Education, Vol.30, No.8, 1055-1073, 2008.

[46] M. R. Matthews. In defense of modest goals when teaching about the nature of science, Journal of Research in Science Teaching, Vol.35, No.2, 161-174, 1998.
[47] M. R. Matthews. Changing the focus: From nature of science (NOS) to features of science (FOS). In M. S. Khine (Ed.), Advances in nature of science research: Concepts and methodologies (pp.3-26), Springer Publishing, New York, NY, 2012.

[48] R. M. Marra, B. Palmer. University science students' epistemological orientations and nature of science indicators: How do they relate?, Science Education International, Vol.18, No.3, 165-184, 2005 .

[49] W. F. McComas, M. P. Clough, H. Almazroa. The role and character of the nature of science in science education. In W. F. McComas (Ed.), The nature of science in science education: Rationales and strategies (pp.3-39), Kluwer Academic Publishers, Dordrecht, The Netherlands, 2002.

[50] J. A. Morrison, F. Raab, D. Ingram. Factors influencing elementary and secondary teachers' views on the nature of science, Journal of Research in Science Teaching, Vol.46, No.4, 384-403, 2009.

[51] M. Niaz. Chemistry education and contributions from history and philosophy of science, Springer International Publishing, Switzerland, 2016.

[52] J. Osborne, S. Simon, S. Collins. Attitudes towards science: A review of the literature and its implications, International Journal of Science education, Vol.25, No.9, 1049-1079, 2003.

[53] M. Ozel. Children's images of scientists: Does grade level make a difference?, Educational Sciences: Theory \& Practice, Vol.12, No.4, 3187-3198, 2012

[54] M. Pigliucci. Nonsense on stilts: How to tell science from bunk, The University of Chicago Press, Chicago, IL, 2010.

[55] T. J. Posnanski. Developing understanding of the nature of science within a professional development program for inservice elementary teachers: Project nature of elementary science teaching, Journal of Science Teacher Education, Vol.21, 589-621, 2010

[56] K. Royal. Understanding reliability in higher education student learning outcomes assessment, Quality Approaches in Higher Education, vol.2, No.2, 8-15, 2011.

[57] J. M. Ruane. Essentials of research methods: A guide to social science research, Blackwell Publishing, Malden, MA, 2005.

[58] T. D. Sadler, F. W. Chambers, D. L. Zeidler. Student conceptualization of the nature of science in response to a socioscientific issue, International Journal of Science education, Vol.26, No.4, 387-409, 2004.

[59] L. C. Scharmann, M. U. Smith, M. C. James, M. Jensen. Explicit reflective nature of science instruction: Evolution, intelligent design, and umbrellaology, Journal of Science Teacher Education, Vol.16, 27-41, 2005

[60] D. Schizas, D. Psillos, G. Stamou. Nature of science or nature of the sciences?, Science Education, Vol.100, No.4, 706-733, 2016.

[61] R. S. Schwartz, N. G. Lederman, B. A. Crawford. Developing views of nature of science in an authentic context: An explicit approach to bridging the gap between nature of science and scientific inquiry, Science Education, Vol.88, 610-645, 2004.

[62] S. Tala, V. Vesterinen. Nature of science contextualized: Studying nature of science with scientists, Science \& Education, Vol.24, 435-457, 2015. 
[63] H. Turkmen. Turkish primary students' perceptions about scientist and what factors affecting the image of the scientists, Eurasia Journal of Mathematics, Science \& Technology Education, Vol.4, No.1, 55-61, 2008.

[64] UNESCO. Science, technology and gender: An international report, The United Nations Educational, Scientific and Cultural Organization, Paris, France, 2007.
[65] S. L. Wong, D. Hodson. From the horse's mouth: What scientists say about scientific investigation and scientific knowledge, Science Education, Vol.93, 1-22, 2008.

[66] A. Field. Discovering statistics using SPSS, Sage Publications, Thousand Oaks, CA, 2009.

[67] G. Leblebicioglu, D. Metin, E. Yardimci, P. S. Cetin. The effect of informal and formal interaction between scientists and children at a science camp on their images of scientists, Science Education International, Vol.22, No.3, 158-174, 2011. 